\title{
DETERMINATION OF ANTHOCYANIN CONTENT AND ANTIOXIDANT CAPACITY OF DIFFERENT GRAPE VARIETIES
}

\section{DETERMINAÇÃO DA COMPOSIÇÃO ANTOCIÂNICA E DA ACTIVIDADE ANTIOXIDANTE DA UVA DE DIFERENTES VARIEDADES DE VIDEIRA}

\author{
Shivraj Hariram Nile*, Doo Hwan Kim, and Young-Soo Keum
}

Department of Bioresources and Food Science, College of Life and Environmental Sciences, Konkuk University, Seoul, South Korea.

*corresponding author: Tel: +82024503739, fax: +820234365439, e-mail: nileshivraj@gmail.com and nileshivraj@rediffmail.com

(Received 27.08.2015. Accepted 05.11.2015)

SUMMARY

The aim of this study was to determine anthocyanin content and antioxidant activity of 20 different grape varieties, using HPLC and DPPH, FRAP and ABTS assays, respectively. The identified anthocyanins were malvidin-3-glucoside, delphinidin-3-glucoside, petunidin-3-glucoside, cyanidin3 glucoside, and peonidin-3-glucoside on the basis of their retention times. Comparatively the total anthocyanin content varied from 181.2 mg/ 100 g FW ('Vidal Black') to 716.4 mg/ 100 g FW ('Catawba'). High anthocyanin content was found in 'Catawba' (716.4 mg/100 g), 'Ruby Seedless' (634.5 mg/100 g) and 'Campbell Early’ (611.1 mg/100 g) extracts. The antioxidant activities of grape extracts varied from 32.8\% ('Campbell Early') to 87.6\% ('Hongiseul') by DPPH, 79.1\% ('Campbell Early') to 197\% ('Hongiseul') in case of FRAP and $11.1 \%$ ('Chasselas Rouge') to $74.5 \%$ ('Flouxa') by ABTS antioxidant assay. The results suggested that the anthocyanin content in studied grape varieties showed statistically significant correlation with free radical scavenging activity. Thus depending on results we say that these grape varieties may serve as a potential source of nutraceuticals and functional food development.

\section{RESUMO}

O objectivo do presente estudo foi determinar a composição antociânica e a actividade antioxidante da uva de 20 variedades de videira, por HPLC e através dos métodos DPPH, FRAP e ABTS, respectivamente. As antocianinas identificadas foram a malvidina-3-glucósido, delfinidina-3glucósido, petunidina-3-glucósido, cianidina-3-glucósido e peonidina-3-glucósido, de acordo com os seus tempos de retenção. O teor total de antocianinas variou entre 181,2 mg/ 100 g FW ('Vidal Black') e 716,4 mg/ 100 g FW ('Catawba'). Os teores mais elevados foram detectados nos extractos de uvas das variedades 'Catawba' (716,4 mg/100 g), 'Ruby Seedless' (634,5 mg/100 g) e 'Campbell Early' (611,1 mg/100 g). A actividade antioxidante dos extractos de uvas variou entre 32,8\% ('Campbell Early') e 87,6\% ('Hongiseul') pelo método DPPH, entre 79,1\% ('Campbell Early') e 197\% ('Hongiseul') pelo método FRAP, e entre 11,1\% ('Chasselas Rouge') e 74,5\% ('Flouxa') pelo método ABTS. Os resultados sugerem que a composição antociânica nas variedades estudadas apresenta uma correlação significativa com a actividade antiradicalar. Assim, considera-se que as uvas destas variedades de videira podem constituir uma fonte potencial de compostos nutracêuticos e com interesse no desenvolvimento de alimentos funcionais.

Key words: grape, HPLC, anthocyanin, antioxidant.

Palavras-chave: uva, HPLC, antocianinas, antioxidante.

\section{INTRODUCTION}

Anthocyanins constitute a large family of polyphenols in plants and are responsible for many of the fruit and floral colours observed in nature (Nile and Park, 2014a). They are pigments dissolved in the vacuolar sap of the epidermal tissues of flowers and fruit which impart a pink, red, blue, or purple colour (Mazza and Maniati, 1993). Accumulating data show that anthocyanins and anthocyanin-rich plant extracts could provide various health benefits, including protection from DNA cleavage (Lazze et al., 2003), anti- inflammatory activity (Rossi et al., 2003), anticancer activity (Hou, 2003; Hou et al., 2004), antioxidant activity (Matsumoto et al., 2002; Oh et al., 2008), anti-diabetic activity (Jankowski et al., 2000; Tsuda et al., 2003), and prevention of cardiovascular and neurodegenerative disease (Youdim et al., 2000). Many of the grape varieties like 'Catawba', 'Concord', 'Niagara', ‘Ontario', 60

This is an Open Access article distributed under the terms of the Creative Commons Attribution License (http://creativecommons.org/licenses/by/4.0), which permits unrestricted use, distribution, and reproduction in any medium, provided the original work is properly cited. 
'Delaware' and 'Thomson Seedless' has been originated and developed from the early 20th century (Paul and Sanjun, 2003; Chiou et al., 2007). Grapes are among the fruits containing the highest content of phenolic substances, which are partially extracted during wine making process and brewing (Revilla and Ryan, 2002). Many grape berries having significant amount of bioactive phenolics with antioxidant properties (including flavan-3-ols, anthocyanins, cinnamic acid derivatives, flavonol derivatives and trans-resveratrol) that may be separated in a single run by direct injection of red wine (Burns et al., 2000). The phenolic compounds in fresh and commercial grape juices may also be beneficial in the prevention of coronary heart diseases as they also have strong antioxidant activity towards human LDL oxidation in vitro (Meyer et al., 1998). South Korea is bestowed with diverse climatic conditions and conducive for the growth of different grapes known for their nutritional and wine producing values (Nile et al., 2013). So far, there has not been any study on antioxidant activity of grape cultivars grown and consumed South Korea. The main objective of this study was to screen a large number of grapes cultivars grown and consumed in the Korean diet and wine industry with respect to their total anthocyanin content and antioxidant activity. Based on the above facts, the objectives of our work was to quantify anthocyanins and antioxidant activity from grape fractions of twenty different cultivars that are available in South Korea. Such studies are of particular importance because anthocyanins have been shown to differ considerably in their bioavailability and to exert different biological activities in vitro and in vivo. Thus, this data may contribute to the selection of suitable grape material for the extraction of phytochemicals as ingredients for nutraceuticals and functional food development.

\section{MATERIAL AND METHODS}

\section{Materials}

The 20 grape cultivars were obtained from vineyards from Suwon, Gyeonggi, Jeju and Muan, different geographic regions of Korea in 2012 (Table I). $5 \mathrm{Kg}$ each fruits were harvested in summer after fully maturation, stored for about 5 months at $-400 \mathrm{C}$, homogenized with food processor, and lyophilized to concentrate each sample.

Table I

Classification of grape cultivars according to skin colour

Classificação das variedades de videira de acordo com a cor da película

\begin{tabular}{cccc}
\hline Skin colour & V. vinifera & V. labrusca & V. hybrida \\
\hline \multirow{2}{*}{ White } & Vidal Black & Niagara & Thomson Green (seedless) \\
& Italia & Catawba & Ontario \\
& & & \\
Red & Chasselas Rouge & Delawere & Hongiseul \\
& Red globe & Ruby Seedless & Honey Red \\
& & Koho & \\
Black & Alphonse Lavallee & Concord & Flouxa \\
& & Campbell Early & Tamnara \\
& & Sherpher & Black Pegaru \\
\hline
\end{tabular}

\section{Chemicals}

Anthocyanin standards: HPLC grade malvidin-3-Oglucoside chloride, delphinidin 3-O- $\beta$-D-glucoside chloride, petunidin-3-O-glucoside chloride, cyanidin-
3-O-glucoside chloride, and peonidin-3-O-glucoside chloride, Sigma Chemical Co. (St. Louis, MO), DPPH were obtained from Fluka Chemicals AG (Buchs, Switzerland). All other chemicals were procured from Daejung Chemicals, Seoul, South Korea (Kallithraka et al., 2005). 


\section{Extraction of grape sample}

A lot of $1 \mathrm{~kg}$ grape berries was carefully collected in the vineyard, cut from the clusters with the pedicel, and transferred quickly to the laboratory. Pedicels were removed and berries were weighted, manually skinned, and the skins were freeze-dried. The freezedried tissues were then extracted with $200 \mathrm{~mL}$ of $1 \%$ $\mathrm{HCl}$ in methanol. Extraction was carried out under stirring for $48 \mathrm{~h}$, and repeated in triplicate. Extracts were pooled, and this mixture was used for further procedures after deep-freezing $\left(-70^{\circ} \mathrm{C}\right)$ for no longer than 3 days.

\section{HPLC analysis}

The HPLC/DAD analysis was performed on a Shimadzu HPLC equipped with a diode array detector (SPD-M10A, Shimadzu, Japan) at $520 \mathrm{~nm}$ for quantification. The column used was a $\mathrm{C} \neg 18$ HPLC column (Zorbax 300SB-C18, Agilent Technologies, Ris $\neg$ ing Sun, Md., USA). A temperature programmable column oven (Younglin Instrument, Seoul, Korea) was used to maintain the column temperature at $35^{\circ} \mathrm{C}$ during the HPLC analysis. The injection volume of the prepared sample was $10 \mu \mathrm{L}$. Solvent A was formic acid/water (10:90), and solvent $\mathrm{B}$ was formic acid/acetonitrile (10:90). The solvent gradient for all grape samples and reference standards (malvidin-3-O-glucoside chloride, delphinidin 3-O- $\beta$ D-glucoside chloride, petunidin-3-O-glucoside chloride, cyanidin-3-O-glucoside chloride, and peonidin-3-O-glucoside chloride) was 0 to $10 \mathrm{~min}$, $10 \% \mathrm{~B} ; 10$ to $20 \mathrm{~min}, 10 \%$ to $20 \% \mathrm{~B} ; 20$ to $30 \mathrm{~min}$, $15 \%$ to $25 \% \mathrm{~B}$; and 35 to $50 \mathrm{~min}, 30 \% \mathrm{~B}$ (Oh et al., 2008).

\section{Total anthocyanin content}

Total anthocyanin content was determined using a previously described method (Connor et al., 2002), in which each grape extract was diluted $(5: 95, \mathrm{v} / \mathrm{v})$ in $1 \% \mathrm{HCl}$ in methanol to obtain an absorbance between 0.500 and 1.000 at $530 \mathrm{~nm}$. The values were expressed as $\mathrm{mg}$ cyanidin-3-glucoside (c3g) equivalents per $100 \mathrm{~g}$ fresh weight using a molar extinction coefficient of 27.900. All determinations were performed in triplicates.

\section{DPPH free radical scavenging activity}

The bleaching rate of a stable free radical DPPH was monitored at a characteristic wavelength in the presence of the grape sample. In this, radical form of DPPH absorbs at $517 \mathrm{~nm}$ upon reduction by an antioxidant. This activity was measured according the previously described method, briefly as: $100 \mu \mathrm{M}$ solution of DPPH was prepared in $10 \mathrm{~mL}$ of methanol and $2.7 \mathrm{~mL}$ of this solution was added to $0.5 \mathrm{~mL}$ of grape extract in methanol at the same concentration $(0.1 \mathrm{mg} / \mathrm{mL})$. After $10 \mathrm{~min}$, the absorbance was measured at $517 \mathrm{~nm}$. The percentage of remaining DPPH was calculated as, DPPH scavenging effect $(\%)=[($ AControl - ASample/AControl $) \times 100]$, Where AControl is the absorbance of the DPPH reaction and ASample is the absorbance in the presence of grape extracts. All determinations were performed in triplicate (Nile et al., 2013).

\section{Ferric reducing antioxidant power (FRAP) assay}

The assay was based on the reducing power of a compound (antioxidant) as previously described (Nile and Park, 2014b). A potential antioxidant will reduce the ferric ion $\left(\mathrm{Fe}^{3+}\right)$ to the ferrous ion $\left(\mathrm{Fe}^{2+}\right)$; the latter forms a blue complex $\left(\mathrm{Fe}^{2+} / \mathrm{TPTZ}\right)$, which increases the absorption at $593 \mathrm{~nm}$. Briefly, the FRAP reagent was prepared by mixing acetate buffer $(300 \mu \mathrm{M}, \mathrm{pH}$ 3.6), a solution of $10 \mu \mathrm{M}$ TPTZ in $20 \mu \mathrm{M} \mathrm{HCl}$, and 10 $\mu \mathrm{M} \mathrm{FeCl} l_{3}$ at $10: 1: 1(\mathrm{v} / \mathrm{v} / \mathrm{v})$. The reagent $(300 \mu \mathrm{L})$ and sample solutions $(10 \mu \mathrm{L})$ were added to each well and mixed thoroughly. The absorbance was taken at 593 $\mathrm{nm}$ after $10 \mathrm{~min}$. Standard curve was prepared using different concentrations of Trolox. The results were corrected for dilution and expressed in micromolar Trolox per $100 \mathrm{~g}$ of dry weight (DW). All determinations were performed in triplicate.

\section{Free radical scavenging ability by ABTS}

The free-radical-scavenging activity was determined by ABTS radical cation decolorization assay (Nile and Park, 2014c). ABTS was dissolved in water to a 5 $\mathrm{mM}$ concentration. ABTS radical cation $\left(\mathrm{ABTS}^{\circ+}\right)$ was produced by reacting ABTS stock solution with $2.50 \mathrm{mM}$ potassium persulfate (final concentration) and kept in the dark at room temperature for 12-16 h before use. The radical was stable in this form for more than 2 days when stored in the dark at room temperature. For the study of infusion, the samples containing the $\mathrm{ABTS}^{-+}$solution were diluted with redistilled water to an absorbance of $0.700(0.02)$ at $734 \mathrm{~nm}$ and equilibrated at $30^{\circ} \mathrm{C}$. After the addition of $3.0 \mathrm{~mL}$ of diluted $\mathrm{ABTS}^{\circ+}$ solution $(\mathrm{A} 734 \mathrm{~nm})$ $0.700(0.02)$ to $10 \mu \mathrm{L}$ of polyphenolic extracts of grape, the absorbance reading was exactly 6 min after initial mixing. The results were corrected for dilution and expressed in micromolar Trolox per $100 \mathrm{~g}$ of dry weight (DW). All determinations were performed in triplicate.

\section{Statistical analysis}

The experiments were performed in triplicate. The results were expressed as mean $\pm \mathrm{SD}$. Also, linear regressions between the content of total anthocyanins with the results of the antioxidant assays were assessed. 


\section{RESULTS AND DISCUSSION}

All grape samples were analyzed by HPLC to quantify their anthocyanins. The obtained results revealed differences in the concentrations of total anthocyanins in grapes according to the variety (Table II). Baseline separation of all anthocyanins was achieved within $30 \mathrm{~min}, 4$ of them being identified as the malvidin-3-glucoside, delphinidin-3glucoside, petunidin-3-glucoside, cyanidin-3 glucoside, and peonidin-3-glucoside on the basis of their HPLC retention times by comparison with those of reference compounds (peak 1-5, Figure 1). The total anthocyanin content varied from $181.2 \mathrm{mg} / 100$ g FW ('Vidal Black') to $716.4 \mathrm{mg} / 100 \mathrm{~g}$ FW ('Catawba'). High anthocyanin content was found in 'Catawba' (716.4 mg/100 g), 'Ruby Seedless' (634.5 mg/100 g) and 'Campbell Early' (611.1 mg/100 g) extracts. Most of black skin colour grape cultivars were rich in cyanidin-3 glucoside, this cyanidin-3 glucoside anthocyanin varying from 32.5 ('Vidal Black') to 89.5 ('Hongiseul') mg/100 g fresh weight. Malvidin-3-glucoside varied from 32.8 ('Campbell Early') to 87.6 ('Hongiseul') mg/100 g fresh weight. Delphinidin-3-glucoside varied from 80.9 ('Honey Red') to 456.8 ('Catawba') mg/100 g fresh weight. Peonidin-3-glucoside varied from 11.1 ('Chasselas Rouge') to 74.5 ('Flouxa') mg/100g fresh weight. Petunidin-3-glucoside varied from 12.6 ('Vidal Black') to 65.9 ('Flouxa') mg/100g fresh weight. The other anthocyanin profile was distinctive for each cultivar, but the degree of ripeness may be critical in this respect, because anthocyanin distribution can be considerably affected during different maturation stages of grape fruits.

Table II

Individual anthocyanin content in grape varieties (Vitis vinifera, Vitis labrusca and Vitis hybrida) extracts ${ }^{\mathrm{a}}$

Teores de antocianinas nos extractos de uvas de diversas variedades (Vitis vinifera, Vitis labrusca and Vitis hybrida) ${ }^{a}$

\begin{tabular}{|c|c|c|c|c|c|c|c|}
\hline \multirow{2}{*}{ Sr. No } & \multirow{2}{*}{ Varieties } & \multicolumn{6}{|c|}{ Anthocyanin content (mg $100 \mathrm{~g}^{-1} \mathrm{FW}$ ) } \\
\hline & & $\begin{array}{c}\text { malvidin-3- } \\
\text { glucoside }\end{array}$ & $\begin{array}{l}\text { delphinidin-3- } \\
\text { glucoside }\end{array}$ & $\begin{array}{l}\text { peonidin-3- } \\
\text { glucoside }\end{array}$ & $\begin{array}{l}\text { cyanidin-3 } \\
\text { glucoside }\end{array}$ & $\begin{array}{l}\text { petunidin-3- } \\
\text { glucoside }\end{array}$ & $\begin{array}{c}\text { Total } \\
\text { anthocyanin }\end{array}$ \\
\hline 1 & Thomson Green (seedless) & $42.2 \pm 2.1$ & $134.0 \pm 1.4$ & $28.0 \pm 2.2$ & $40.2 \pm 1.2$ & $24.1 \pm 1.0$ & $268.5 \pm 7.9$ \\
\hline 2 & Vidal Black & $34.5 \pm 1.3$ & $86.7 \pm 2.0$ & $14.9 \pm 0.4$ & $32.5 \pm 1.1$ & $12.6 \pm 0.5$ & $181.2 \pm 5.3$ \\
\hline 3 & Italia & $48.5 \pm 4.1$ & $283.2 \pm 3.3$ & $28.0 \pm 1.5$ & $38.5 \pm 1.4$ & $30.1 \pm 1.2$ & $428.3 \pm 11.5$ \\
\hline 4 & Niagara & $60.1 \pm 3.1$ & $88.2 \pm 1.6$ & $20.7 \pm 1.2$ & $58.4 \pm 2.3$ & $22.1 \pm 1.6$ & $249.5 \pm 9.8$ \\
\hline 5 & Catawba & $56.1 \pm 1.5$ & $456.8 \pm 2.4$ & $52.5 \pm 2.8$ & $50.4 \pm 1.7$ & $48.6 \pm 1.4$ & $716.4 \pm 9.8$ \\
\hline 6 & Ontario & $71.5 \pm 2.4$ & $196.3 \pm 2.6$ & $17.4 \pm 1.7$ & $72.4 \pm 1.8$ & $15.6 \pm 1.0$ & $373.2 \pm 9.5$ \\
\hline 7 & Hongiseul & $87.6 \pm 2.4$ & $217.0 \pm 2.2$ & $18.2 \pm 1.4$ & $89.5 \pm 2.7$ & $20.2 \pm 1.8$ & $432.5 \pm 10.5$ \\
\hline 8 & Delaware & $67.5 \pm 2.3$ & $218.9 \pm 2.7$ & $25.9 \pm 1.9$ & $70.2 \pm 1.5$ & $20.1 \pm 2.4$ & $402.6 \pm 10.8$ \\
\hline 9 & Ruby Seedless & $72.5 \pm 2.2$ & $432.5 \pm 3.6$ & $36.0 \pm 2.4$ & $75.2 \pm 1.2$ & $18.3 \pm 1.6$ & $634.5 \pm 11$ \\
\hline 10 & Chasselas Rouge & $80.1 \pm 2.1$ & $102.9 \pm 1.8$ & $11.1 \pm 3.6$ & $84.1 \pm 2.1$ & $15.3 \pm 1.7$ & $293.5 \pm 11.3$ \\
\hline 11 & Honey Red & $63.6 \pm 1.4$ & $80.9 \pm 3.2$ & $13.6 \pm 1.7$ & $65.2 \pm 1.5$ & $14.8 \pm 1.2$ & $238.1 \pm 9$ \\
\hline 12 & Red Globe & $48.2 \pm 1.8$ & $165.0 \pm 1.3$ & $25.3 \pm 0.9$ & $50.1 \pm 1.1$ & $22.6 \pm 1.4$ & $311.2 \pm 6.5$ \\
\hline 13 & Koho & $59.0 \pm 3.1$ & $364.2 \pm 1.9$ & $39.0 \pm 2.6$ & $62.2 \pm 1.4$ & $35.4 \pm 2.1$ & $559.8 \pm 11.1$ \\
\hline 14 & Flouxa & $78.2 \pm 3.2$ & $186.0 \pm 2.5$ & $74.5 \pm 1.8$ & $80.5 \pm 2.1$ & $65.9 \pm 1.8$ & $485.1 \pm 9.6$ \\
\hline 15 & Black Pegaru & $40.2 \pm 1.9$ & $85.9 \pm 2.8$ & $15.4 \pm 2.4$ & $45.3 \pm 1.3$ & $18.5 \pm 1.0$ & $205.3 \pm 9.4$ \\
\hline 16 & Sherpher & $56.3 \pm 1.4$ & $223.2 \pm 2.8$ & $20.4 \pm 1.6$ & $58.6 \pm 1.4$ & $25.4 \pm 2.1$ & $383.9 \pm 9.3$ \\
\hline 17 & Concord & $37.7 \pm 3.1$ & $199.1 \pm 1.8$ & $17.7 \pm 0.9$ & $41.2 \pm 1.6$ & $15.6 \pm 1.2$ & $311.3 \pm 8.6$ \\
\hline 18 & Campbell Early & $32.8 \pm 1.4$ & $449.1 \pm 2.9$ & $48.2 \pm 2.0$ & $35.8 \pm 2.2$ & $45.2 \pm 2.0$ & $611.1 \pm 10.5$ \\
\hline 19 & Alphonse Lavallee & $48.6 \pm 2.7$ & $277.8 \pm 4.7$ & $38.2 \pm 1.2$ & $50.6 \pm 1.7$ & $35.1 \pm 2.1$ & $450.3 \pm 12.4$ \\
\hline 20 & Tamnara & $38.2 \pm 2.6$ & $85.6 \pm 2.1$ & $13.7 \pm 1.7$ & $42.5 \pm 1.1$ & $20.1 \pm 1.2$ & $200.1 \pm 8.7$ \\
\hline
\end{tabular}

${ }^{a}$ Values are expressed as mean $\pm \mathrm{SD}(n=3)$. All values area expressed as cyanidin-3-rutinoside equivalents. 


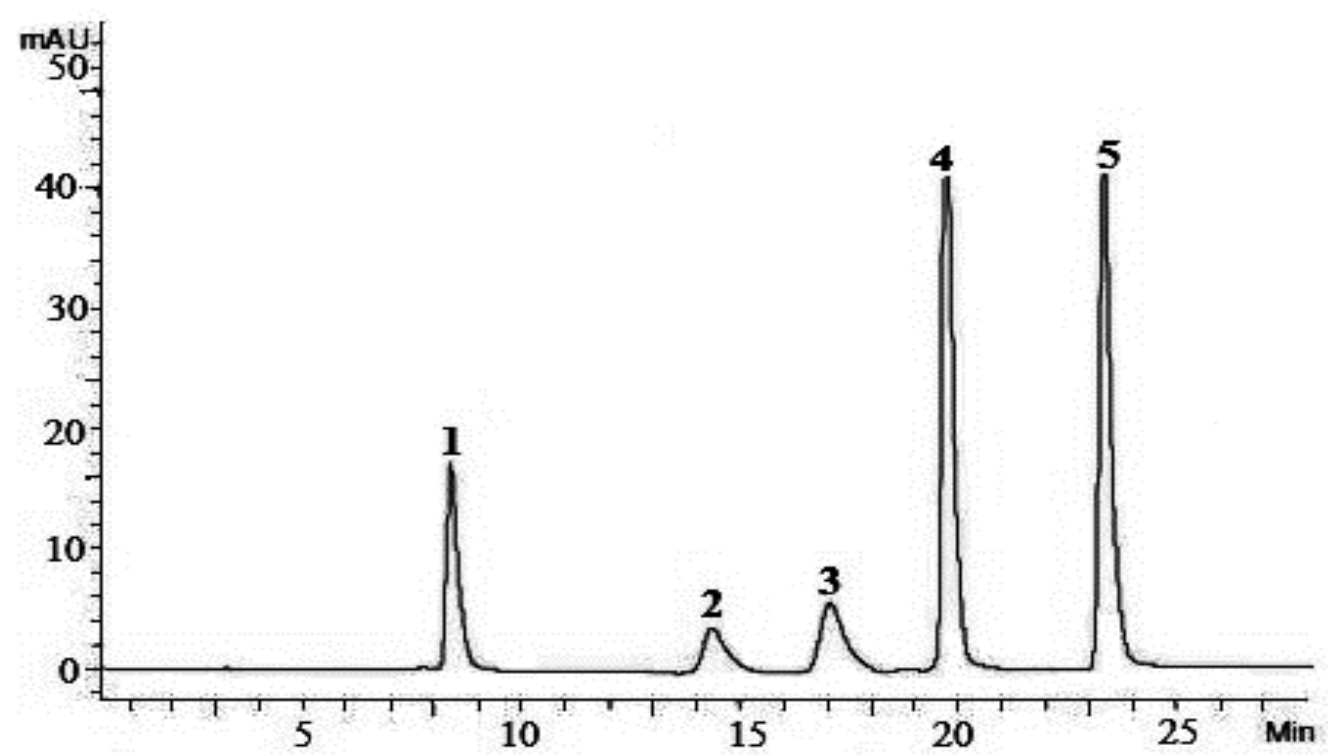

Figure 1. HPLC separation of reference anthocyanins $(520 \mathrm{~nm}) .1$ : Delphinidin-3-O- $\beta$-D-glucoside; 2 : Cyanidin-3-O-glucoside; 3: Petunidin-3- $O$ glucoside; 4: Peonidin-3-O-glucoside; 5: Malvidin-3-O-glucoside.

Separação de antocianinas de referência por HPLC (520 nm). 1: Delfinidina-3-O- $\beta$-D-glucósido; 2: Cianidina-3-O-glucósido; 3: Petunidina-3O-glucósido; 4: Peonidina-3-O-glucósido; 5: Malvidina-3-O-glucósido.

The phenolics, flavonoids and anthocyanins are the main class of natural compounds with significant antioxidant activities which have been identified and quantified in several fruits, vegetables and berries (Rockenbach et al., 2011; Nile and Park, 2014a). Grapes and wine contains high amounts of phenolics, flavonoids and anthocyanins and acts as antioxidants (Yildirim et al., 2005). Also it was found that the grape extracts consist of high amount of anthocyanins from the skin and procyanidins from the seeds (Shrikhande, 2000). Phenolics, flavonoids and anthocyanins are primary antioxidants which can donate hydrogen or electron, and radical intermediates can be stabilized by these types of compounds (Yilmaz and Toledo, 2006). Ricardo-daSilva et al. (1991) studied and found that the FRAP values of grape extracts were reported to be highly correlated with total anthocyanin content and ABTS radical scavenging activity values. In the present study, we also found that total anthocyanin content were highly correlated with antioxidant activity (FRAP, DPPH and ABTS) of grape extracts (Figure 2). Thaipong et al. (2006) also reported a positive correlation coefficient between the total phenolic content and antioxidant activity of methanolic extracts of guava fruit by comparing ABTS, DPPH, FRAP, and ORAC assays. Concerning the study of antioxidant effectiveness, the use of different in vitro models has recently been recommended, due to the differences between the various free radical scavenging assay systems (Ruberto et al., 2007). Thus, the determination of the antioxidant activity of the extracts was carried out using the ABTS and DPPH methods and reducing power through the FRAP method (Table III). Therefore, the ripening stage may be a major factor for anthocyanin levels in grape together with the cultivars. The effects of free radical scavenging by DPPH, FRAP and ABTS radical for all samples are shown in Table III. The antioxidant activities of grape extracts varied from $32.8 \%$ ('Campbell Early') to $87.6 \%$ ('Hongiseul') by DPPH. The radical scavenging activities of grape extracts varied from $79.1 \%$ ('Campbell Early') to $197 \%$ ('Hongiseul') by FRAP assay and in case of ABTS assay the scavenging activities of grape extracts varied from $11.1 \%$ ('Chasselas Rouge') $74.5 \%$ ('Flouxa'). The contents of anthocyanin in grape demonstrated lower correlations with the effects of free radical scavenging by ABTS radical. These results were similar to those of a previous study (Kallithraka et al., 2005). The results presented herein provided valuable data with regard to anthocyanin composition of several technologically important wine grape varieties from Korea. The vinification of grapes with high anthocyanin potential has been regarded as a principal criterion for grapes, 
which are enriched with these biologically active phenolic compounds like anthocyanins. In some small fruits like raspberries, sweet potatoes and cranberries the antioxidant capacity has been correlated to a significant degree with anthocyanin content, indicating that anthocyanins may govern the antioxidant capacity of several plant tissues to a certain extent. In grapes, however, fractions containing cyanidin-3 glucoside has efficient activity as inhibiting the LDL oxidation whereas; the highest activity was seen with fractions containing flavonols in grapes (Oki et al., 2002; Wada and Ou, 2002). According to many studies antioxidant activity of fruits, results mainly from phenolics, particularly flavonoids and found a strong correlation among antioxidant capacity, total phenols and anthocyanins (Kalt et al., 1999; Wang and Lin, 2000). On the other hand, some investigations also indicated that anthocyanins may be less significantly correlated with the antioxidant properties (Burns et al., 2000; Arnous et al., 2002). These results presented herein provided valuable data for the total anthocyanin content and antioxidant activity of several commercially important grape varieties from South Korea. Furthermore, the correlation of the antioxidant activity and total anthocyanins was found to be significant (Figure 2) and which was similar and comparative with previous studies.
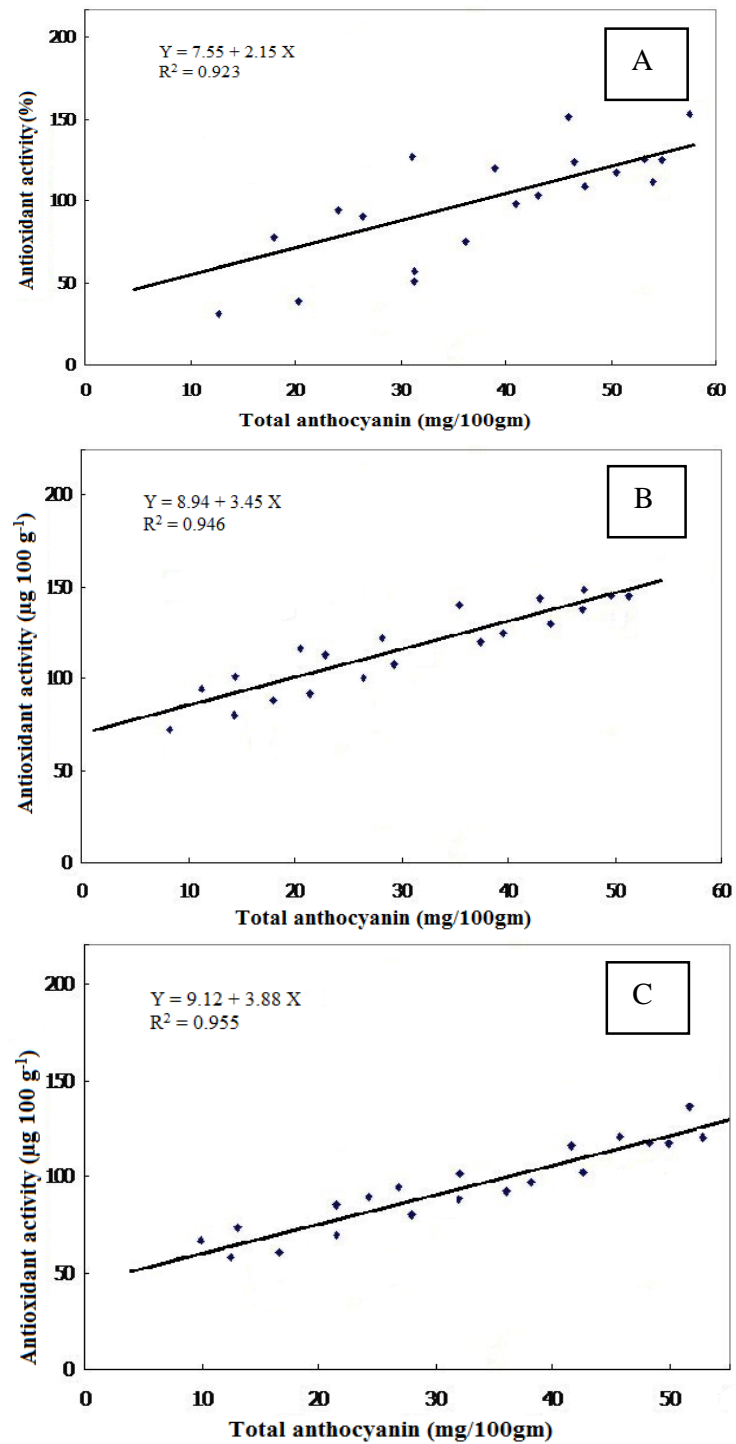

Figure 2. Correlation of total anthocyanin content and antioxidant activity (\%) in grapes (A: DPPH assay, B: FRAP assay, C: ABTS assay). Correlação entre o teor total de antocianinas e a actividade antioxidante (\%) das uvas (A: método DPPH; B: método FRAP; C: método ABTS). 
Table III

Antioxidant activity of grape varieties

Actividade antioxidante das uvas das diversas variedades

\begin{tabular}{|c|c|c|c|c|}
\hline & \multirow[t]{2}{*}{ Grape varieties } & \multicolumn{3}{|c|}{ Antioxidant activity ${ }^{\mathrm{a}, \mathrm{b}}$} \\
\hline & & DPPH & FRAP & ABTS \\
\hline 1 & Thomson Green (seedless) & $42.2 \pm 2.2$ & $88.2 \pm 1.4$ & $28.0 \pm 2.2$ \\
\hline 2 & Vidal Black & $34.5 \pm 1.3$ & $86.7 \pm 2.0$ & $14.9 \pm 0.4$ \\
\hline 3 & Italia & $48.5 \pm 4.1$ & $113.2 \pm 3.3$ & $28.0 \pm 2.2$ \\
\hline 4 & Niagara & $60.1 \pm 3.1$ & $134.0 \pm 1.6$ & $20.7 \pm 1.7$ \\
\hline 5 & Catawba & $56.1 \pm 1.5$ & $156.8 \pm 2.4$ & $52.5 \pm 2.8$ \\
\hline 6 & Ontario & $71.5 \pm 2.4$ & $190.3 \pm 2.6$ & $17.4 \pm 1.7$ \\
\hline 7 & Hongiseul & $87.6 \pm 2.4$ & $197.0 \pm 2.2$ & $18.2 \pm 2.4$ \\
\hline 8 & Delaware & $67.5 \pm 2.3$ & $148.9 \pm 2.7$ & $25.9 \pm 1.9$ \\
\hline 9 & Ruby Seedless & $72.5 \pm 2.2$ & $162.5 \pm 3.6$ & $16.0 \pm 2.4$ \\
\hline 10 & Chasselas Rouge & $80.1 \pm 2.1$ & $182.9 \pm 1.8$ & $11.1 \pm 3.6$ \\
\hline 11 & Honey Red & $63.6 \pm 1.4$ & $179 \pm 3.2$ & $13.6 \pm 1.7$ \\
\hline 12 & Red globe & $48.2 \pm 1.8$ & $115.0 \pm 1.8$ & $25.3 \pm 0.9$ \\
\hline 13 & Koho & 59. $0 \pm 3.1$ & $134.2 \pm 1.9$ & 39. $0 \pm 2.6$ \\
\hline 14 & Flouxa & $78.12 \pm 3.2$ & $186.0 \pm 2.5$ & $74.5 \pm 1.8$ \\
\hline 15 & Black Pegaru & $40.2 \pm 1.9$ & $85.9 \pm 2.8$ & $15.4 \pm 2.4$ \\
\hline 16 & Sherpher & $56.3 \pm 1.4$ & $123.2 \pm 2.8$ & $20.4 \pm 1.6$ \\
\hline 17 & Concord & $37.7 \pm 3.1$ & $87.2 \pm 3.1$ & $17.7 \pm 0.9$ \\
\hline 18 & Campbell Early & $32.8 \pm 1.4$ & $79.1 \pm 2.9$ & $48.2 \pm 2.0$ \\
\hline 19 & Alphonse Lavallee & $48.6 \pm 2.7$ & $177.8 \pm 4.7$ & $38.2 \pm 1.2$ \\
\hline 20 & Tamnara & $38.2 \pm 2.6$ & $85.6 \pm 6.7$ & $13.7 \pm 1.7$ \\
\hline
\end{tabular}

${ }^{\mathrm{a}} \mathrm{DPPH}$ antioxidant value expressed in percent inhibition and ${ }^{\mathrm{b}} \mathrm{FRAP}$ and ABTS expressed in $\left(\mu \mathrm{g} 100 \mathrm{~g}^{-1}\right)$.Values are expressed as means of three determinations \pm standard deviation.

\section{CONCLUSIONS}

The results obtained in this study showed significant differences among the varieties in relation to the anthocyanin content. The 'Catawba', 'Ruby Seedless' and 'Campbell Early' varieties were richest in total anthocyanins, respectively. Malvidin3-glucoside, delphinidin-3-glucoside, petunidin-3glucoside, cyanidin-3 glucoside, and peonidin-3glucoside was the most abundant anthocyanin compounds identified in grape pomace. The antioxidant activity of extracts obtained from grape pomace showed that of the varieties studied the 'Hongiseul', 'Campbell Early' and 'Flouxa' varieties has the greatest potential as a source of compounds to be applied as natural antioxidants in food. This study showed that the grape varieties rich in anthocyanins might be utilised as functional food and natural remedy against various diseases and disorders related to oxidative stress and free radical effects. Thus, the grape varieties rich in anthocyanins may serve as a new potential source of nutraceuticals and functional food development. From this study we also concludes that the antioxidant assay methods differ from each other in terms of assay principles and reaction conditions, one single method is not enough to show all the antioxidants. Therefore this study compared three most widely used 
spectrophotometric methods. A good correlation between the antioxidant activities determined by DPPH, ABTS, and FRAP methods versus total anthocyanin content was observed for the grapes.

\section{REFERENCES}

Arnous A., Makris D.P., Kefalas P., 2002. Correlation of pigment and flavanol content with antioxidant properties in selected aged regional wines from Greece. J. Food Compos. Analy., 15, 655-665.

Burns J., Gardner P.T., Oneil J., Crawford S., Morecroft I., Mcphail D.B., Lister C., Matthews D., Maclean M.R., Lean M.E., Duthie G.G., Crozier A., 2000. Relationship among antioxidant activity vasodialtion capacity and phenolic content of red wines. $J$. Agric. Food Chem., 48, 220-230.

Chiou A., Karathanos V.T., Mylona A., Salta F.N., Preventi F., Andrikopoulos N.K., 2007. Currants Vitis vinifera L, content of simple phenolics and antioxidant activity. Food Chem., 102, 516522.

Connor A.M., Luby J.J., Tong C.B.S., 2002. Variability in antioxidant activity in blueberry and correlations among different antioxidant activity assays. J. Am. Soc. Hortic. Sci., 127, 238-244.

Hou D.X., 2003. Potential mechanisms of cancer chemoprevention by anthocyanins. Curr, Mole. Med., 3,149-59.

Hou D.X., Kai K., Li J.J., Lin S., Terahara N., Wakamatsu M., Fuji M., Youg M.R., Colburn N., 2004. Anthocyanin inhibits activator protein-I activity and cell transformation: structure activity relationship and molecular mechanisms. Carcinogenesis., 25, 2936.

Jankowski A., Janlowska B., Niwdworok J., 2000. The effect of anthocyanin dye from grapes on experimental diabetes. Folia Medica Cracoviensia., 41, 5-15.

Kallithraka S., Mohdaly A.A., Makris D.P., Kefalas P., 2005. Determination of major anthocyanin pigments in Hellinic native grape varieties Vitis vinifera $\mathrm{sp}$, association with antiradical activity. J. Food Compos. Analy., 18, 375-386.

Matsumoto H., Nakamura Y., Hirayama M., Yoshiki Y., Okubo K., 2002. Antioxidant activity of black currant anthocyanin aglycons and their glycosides measured by chemiluminescence in a neutral $\mathrm{pH}$ region and in human plasma. J. Agric. Food Chem., 50, 50345037.

Mazza G., Maniati E., 1993. Anthocyanins in fruits vegetables and grains. Boca Raton FL: CRC Press, pp. 10-362.

Meyer A.S., Donovan J.L., Pearson D.A., Waterhouse A.L., Frankel E.N., 1998. Fruit hydroxycinnamic acids inhibit human low-density lipoprotein oxidation in vitro. J. Agric. Food Chem., 46, 1783-1787.

Nile S.H., Kim S.H., Ko E.Y., Park S.W., 2013. Polyphenolic contents and antioxidant properties of different grape $(V$. vinifera,V. labrusca, and V. hybrid) Cultivars. BioMed Res. Int., 2013, 1-5.

Nile S.H., Park S.W., 2014a. Edible berries: bioactive compounds and their effect on human health. Nutrition, 30, 134-144.

Nile S.H., Park S.W., 2014b. Antioxidant: $\alpha$-glucosidase and xanthine oxidase inhibitory activity of bioactive compounds from maize (Zea mays L.). Chem. Biol. Drug Des. 83, 119-125.

\section{ACKNOWLEDGMENTS}

This research paper was supported by the KUResearch Professor Program of Konkuk University2015, Konkuk University, Seoul, South Korea.

Nile S.H., Park S.W., 2014c. HPTLC analysis antioxidant, antiinflammatory and antiproliferative activities of Arisaema tortuosum tuber extract. Pharma Biol. 52, 221-227.

Oh Y.S., Lee J.H., Yoon S.H., Oh C.H., Choi D.S., Choe E., Jung M.Y., 2008. Characterization and quantification of anthocyanins in grape juices obtained from the grapes cultivated in Korea by HPLC/DAD HPLC/MS and HPLC/MS/MS. J. Food Sci., 73, C378-C389.

Oki T., Masuda M., Furuta S., Nishiba Y., Terahara N., Suda I. 2002. Involvement of anthocyanins and other phenolic compounds in radical-scavenging activity of purple-fleshed sweet potato cultivars. J. Food Sci., 67, 1752-1756.

Paul E.R., Sanjun G.A., 2003. Century of American Viticulture. Hort Sci., 38, 943-951.

Revilla E., Ryan M., 2002. Analysis of several phenolic compounds with potential antioxidant properties in grape extracts and wines by high-performance liquid chromatography-photodiode array detection without sample preparation. J. Chromatogr A., 881, 461-469.

Ricardo-da-Silva J.M., Darmon N., Fernandez Y., Mitjavila S., 1991. Oxygen free radical scavenger capacity in aqueous models of different procyanidins from grape seeds. J. Agric. Food. Chem., 39, $1549-1552$

Rockenbach I.I., Rodrigues E., Gonzaga L.V., Caliari V., Genovese M.I., Gonçalves A.E.D.S.S., Fett R., 2011. Phenolic compounds content and antioxidant activity in pomace from selected red grapes (Vitis vinifera L. and Vitis labrusca L.) widely produced in Brazil. Food Chem. 127, 174-179.

Rossi A., Serraino I., Dugo P., Di-Paola R., Mondell L., Gerovese T., Morabito D., Dugo G., Sautebin L., Caputi A.P., Cuzzcrea S., 2003. Protective effects of anthocyanins from blackberry in a rat model of acute lung inflammation. Free Rad. Res., 37, 891-900.

Ruberto G., Renda A., Daquino C., Amico V., Spatafora C., Tringali C., Nunziatina-De T., 2007. Polyphenol constituents and antioxidant activity of grape pomace extracts from five Sicilian red grape cultivars. Food Chem., 100, 203-210

Shrikhande A.J., 2000. Wine by-products with health benefits. Food Res. Int. 33, 469-474.

Thaipong K., Boonprakob U., Crosby K., Cisneros-Zevallos L., Byrne D.H., 2006. Comparison of ABTS, DPPH, FRAP, and ORAC assays for estimating antioxidant activity from guava fruit extracts. J. Food Compos. Anal., 19, 669-675.

Wada L., Ou B., 2002. Antioxidant activity and phenolic content of Oregon caneberries. J. Agric. Food Chem., 50, 3495-3500.

Wang S.Y., Lin S., 2000. Antioxidant activity in fruits and leaves of blackberry raspberry and strawberry varies with cultivar and development stage. J. Agric. Food Chem., 48, 140-146.

Yildirim H. K., Akçay Y. D., Güvenç, U., Altindisli A., Sözmen E. Y., 2005. Antioxidant activities of organic grape, pomace, juice, must, wine and their correlation with phenolic content. Int. J. Food Sci. Technol., 40, 133-142. 
Yilmaz Y., Toledo R.T., 2006. Oxygen radical absorbance capacities of grape/wine industry byproducts and effect of solvent type on extraction of grape seed polyphenols. J. Food Compos. Anal., 19, 41-48.
Youdim K., Marin A., Joseph J., 2000. Incorporation of the elderberry anthocyanins by endothelial cells increases protection against oxidative stress. Free Rad. Biol. Med., 29, 51-60. 